\title{
X-Ray Fluorescence Analysis of Ground Coffee
}

\author{
MARÍA CRISTINA HERNÁNDEZ ${ }^{1}$, DARÍO ROMERO ${ }_{1}$, HUMBERTO TORRES ${ }^{1}$, \\ JAVIER MIRANDA ${ }^{2,3^{*}}$, AND A. ENRIQUE HERNÁNDEZ-LÓPEZ² \\ ${ }^{1}$ Facultad de Ciencias, Universidad Nacional Autónoma de México, Circuito Exterior, \\ 04510, Coyoacán, Cd. Mx., MEXICO \\ ${ }^{2}$ Instituto de Física, Universidad Nacional Autónoma de México, Apartado Postal 20- \\ 364, 01000 Álvaro Obregón, Cd. Mx., MEXICO \\ ${ }^{3}$ Centro de Ciencias de la Atmósfera, Universidad Nacional Autónoma de México, \\ Circuito Investigación Científica, 04510, Coyoacán, Cd. Mx., MEXICO \\ *Email: miranda@fisica.unam.mx
}

Published online: August 07, 2017

The Author(s) 2017. This article is published with open access at www.chitkara.edu. in/publications

\begin{abstract}
Coffee is becoming one of the most popular beverages in Mexico. In the present work, X-ray Fluorescence (XRF) was used to determine the contents of several elements (with atomic numbers between 11 and 38) in 11 samples of commercial ground coffee, comparing with another one of soluble coffee and two of used ground coffee. Samples were dried at room temperature and pelletized. XRF analyses were carried out using a spectrometer based on an $\mathrm{Rh} \mathrm{X}$-ray tube, registering the characteristic $\mathrm{X}$-rays with a Silicon Drift Detector. The system detection calibration and accuracy check was performed through the analysis of NIST certified reference materials 1547 (peach leaves), 1570a (spinach leaves), 1573a (tomato leaves), and 1571 (orchid leaves). As a general rule, the elemental concentrations measured are similar in all samples of coffee, in values not exceeding toxic levels. However, the differences among the elemental concentrations are shown.
\end{abstract}

Keywords: Ground coffee, Elemental analysis, XRF, Food analysis.

\section{INTRODUCTION}

Coffee is nowadays among the most popular beverages in Mexico. There was an estimated production in the country of $1 \times 10^{6}$ ton during the cycle 20142015 , in $7.3 \times 10^{5}$ hectares of land. Moreover, coffee consumption grew at a rate of around $5 \%$ per year until 2015 , reaching a total of $1.1 \times 10^{6}$ ton [1].

Journal of Nuclear

Physics, Material

Sciences, Radiation and

Applications

Vol-5 No-1

August 2017

pp. 25-34 
Hernández, M.C. Of this, $78 \%$ corresponds to instant coffee and the remaining $22 \%$ to ground Romero, D.

Torres, $\mathrm{H}$.

Miranda, J. Hernández-López, A.E. coffee.

Coffee is grown as two species: Cofea arabica and Cofea canephora. They are commonly known as arabica and robusta. Its active substance is the alkaloid caffeine. Effects of coffee on human health are still under strong debate. Some authors suggest that drinking two to four cups of coffee per day benefit health, reducing the risk of colon cancer, gallstones, liver cirrhosis and Parkinson's disease [2,3].

Processing starts from green coffee beans subjected to a thermal procedure, ending as roasted coffee beans. To produce instant coffee, the soluble and volatile components of the roasted beans are extracted. They provide the coffee aroma and flavor; it is possible to do it by means of water. Pressurized liquid water heated to around $175^{\circ} \mathrm{C}$ is employed for this process. The coffee concentration in the resulting liquid is then augmented by either evaporation or freeze concentration.

Due to the economical relevance of coffee, extensive research has been published, in particular regarding its elemental composition, using many analytical techniques. For instance, Atomic Absorption Spectroscopy (AAS) was used by Grembecka et al. [3] to determine concentrations of 14 elements, and used them to differentiate the types of coffee (ground, instant) using multivariate statistics. Valentin and Watling [4] employed Inductively Coupled Plasma spectroscopies (ICP) to determine the provenance of coffee samples from 15 countries, based on the contents of 59 elements. Antoine et al. [5], with measurements through Neutron Activation Analysis (NAA) and other methods, determined the origin of ground coffee consumed in Jamaica. Debastiani et al. [6] analyzed Brazilian coffee samples with Particle Induced X-ray Emission (PIXE). Finally, Martín et al. [7] were able to establish differences between arabica and robusta samples based on elemental concentrations measured with ICP.

Furthermore, several studies have been conducted recently to determine the elemental concentrations in several types of food with high consumption in Mexico, employing X-ray spectrometric methods, such as X-ray Fluorescence (XRF) or PIXE. This way, elemental contents in tomato paste samples from five countries were determined using PIXE and ion backscattering [8]. Also, concentrations in many varieties of dried chili peppers were measured with XRF, finding unusually elevated values for $\mathrm{Br}$ [9]. Additionally, the concentrations of 10 elements were determined in commercial breakfast cereals of several types using XRF and PIXE [10].

With all this in mind, it was considered important to start a more thorough characterization of coffee consumed in Mexico, both ground and instant, either 
to determine its nutritional properties, purity, or origin. As a first step, this work is aimed to demonstrate the viability of using XRF to quantify elemental concentrations in ground coffee samples, both fresh and used, as well as instant coffee. The data should provide information about possible differences in several elements, which might be fixed as indicators of coffee properties or provenance.

\section{MATERIALS AND METHODS}

Three types of coffee samples were obtained: ground coffee (11 samples), used ground coffee (two samples), and instant coffee (one sample). All of them were dried at room temperature, ground in an agate mortar and deposited inside polyethylene vials covered with $3.5 \mu \mathrm{m}$ thick $\mathrm{Mylar}^{\circledR}$ films. A description of the samples is presented in Table 1. In general, it was not possible to determine if the samples were arabica or robusta.

$\mathrm{XRF}$ analysis was carried out using a spectrometer based on an $\mathrm{Rh}$ anode $\mathrm{x}$-ray tube [11], with $\mathrm{x}$-ray spectra detection through an Amptek ${ }^{\circledast} \mathrm{X}-123 \mathrm{SDD}$ complete spectrometer (Bedford, MA, USA). The tube operated at a $35 \mathrm{kV}$ voltage and a $500 \mu \mathrm{A}$ current. Under these working conditions, primary photon scattering in the samples was strongly reduced. Collection time for each spectrum was $600 \mathrm{~s}$. The spectra were collected with the attached Amptek ${ }^{\circledR}$ multichannel buffer and a personal computer. Pressure at the irradiation chamber was of the order of $5 \times 10^{-6}$ torr.

Table 1: Description of coffee samples.

\begin{tabular}{cc}
\hline Sample & Type \\
\hline Jekemir & Ground \\
Member's Mark & Ground \\
Los Portales & Ground \\
Member's Mark (arabiga) & Ground \\
Chiapaneco & Ground \\
La Onza (Coatepec) & Ground \\
Capeltic (Chiapas) & Ground \\
Blasón Gourmet & Ground \\
Casero 1 (arabiga) & Ground \\
Casero 2 (arabiga) & Ground \\
Cafesín & Ground and used \\
Diemme & Ground and used \\
Dolce Gosto (Lungo) & Ground (capsule) \\
\hline Nescafé Dolca & Instant \\
\hline
\end{tabular}


Hernández, M.C. Romero, D.

Torres, $\mathrm{H}$.

Miranda, J. Hernández-López, A.E.
The system detection calibration was performed through the analysis of National Institute of Standards and Technology (NIST) certified reference materials 1547 (peach leaves), 1570a (spinach leaves), and 1573a (tomato leaves). Accuracy determination was then done by analyzing a sample of NIST reference material 1571 (orchard leaves). Spectra were deconvoluted with the open-access QXAS computer code [12].

\section{RESULTS AND DISCUSSION}

The first result is the accuracy determination after analysis of the orchard leaves standard (NIST 1571). The elements $\mathrm{P}, \mathrm{S}, \mathrm{Cl}, \mathrm{K}, \mathrm{Ca}, \mathrm{Mn}, \mathrm{Fe}, \mathrm{Cu}, \mathrm{Zn}$, $\mathrm{Br}, \mathrm{Rb}$, and $\mathrm{Sr}$ were detected, quantified, and compared to the values given in the certificate. All of the measured elemental concentrations, except $\mathrm{S}$ and $\mathrm{Cl}$, agree with the certified values within $20 \%$ or are even equal. In the case of $\mathrm{S}$ and $\mathrm{Cl}$ the disagreement (60\% and $-24 \%$, respectively) is explained because their concentrations are not certified in the reference material. The overall consequence is that XRF may be considered as reliable in this study.

Regarding the coffee samples, a total of 14 elements were found: $\mathrm{Na}, \mathrm{Mg}$, $\mathrm{P}, \mathrm{S}, \mathrm{K}, \mathrm{Ca}, \mathrm{Cr}, \mathrm{Mn}, \mathrm{Fe}, \mathrm{Cu}, \mathrm{Zn}, \mathrm{Br}, \mathrm{Rb}$, and $\mathrm{Sr}$. Table 2 displays the average elemental concentrations in ground coffee, as well as the data for used ground coffee and instant coffee, all for dry mass. Experimental uncertainties range from $15 \%$ for trace elements (like $\mathrm{Na}, \mathrm{Mn}, \mathrm{Cu}, \mathrm{Zn}, \mathrm{Sr}$ ), down to $4 \%$ for the major elements $(\mathrm{K}, \mathrm{Ca})$.

The concentrations of nine elements ( $\mathrm{Na}, \mathrm{Mg}, \mathrm{S}, \mathrm{Mn}, \mathrm{Fe}, \mathrm{Cu}, \mathrm{Zn}, \mathrm{Rb}$, $\mathrm{Sr})$ were similar among all the samples, including the used and instant coffee. An exception is $\mathrm{Fe}$ for the Los Portales sample, with a $560 \mathrm{mg}$ $\mathrm{kg}^{-1}$ value, which is extremely high and may be attributed to the grinding machine used to process the roasted coffee. Nevertheless, the remaining elements showed strong differences among new ground coffee, used coffee, and instant coffee. Figure 1 presents the major nutrients $\mathrm{Na}, \mathrm{P}, \mathrm{K}$, and $\mathrm{Ca}$ data for all samples, while Figure 2 displays concentrations of $\mathrm{Cr}$ and $\mathrm{Br}$. In the case of $\mathrm{Na}$, it is readily seen that no pattern can be identified for the three kinds of samples, as stated above. However, P, K, and Ca are strongly reduced in the used samples, most probably by a scavenging process by hot water during the brewing process. Additionally, $\mathrm{Cr}$ is increased in the Cafesin sample, possibly because a contamination from the coffee maker. Finally, the instant coffee sample Dolca has very high contents of Br. This is not easily explained, unless the manufacturer employs some Br-based compound as pesticide. 


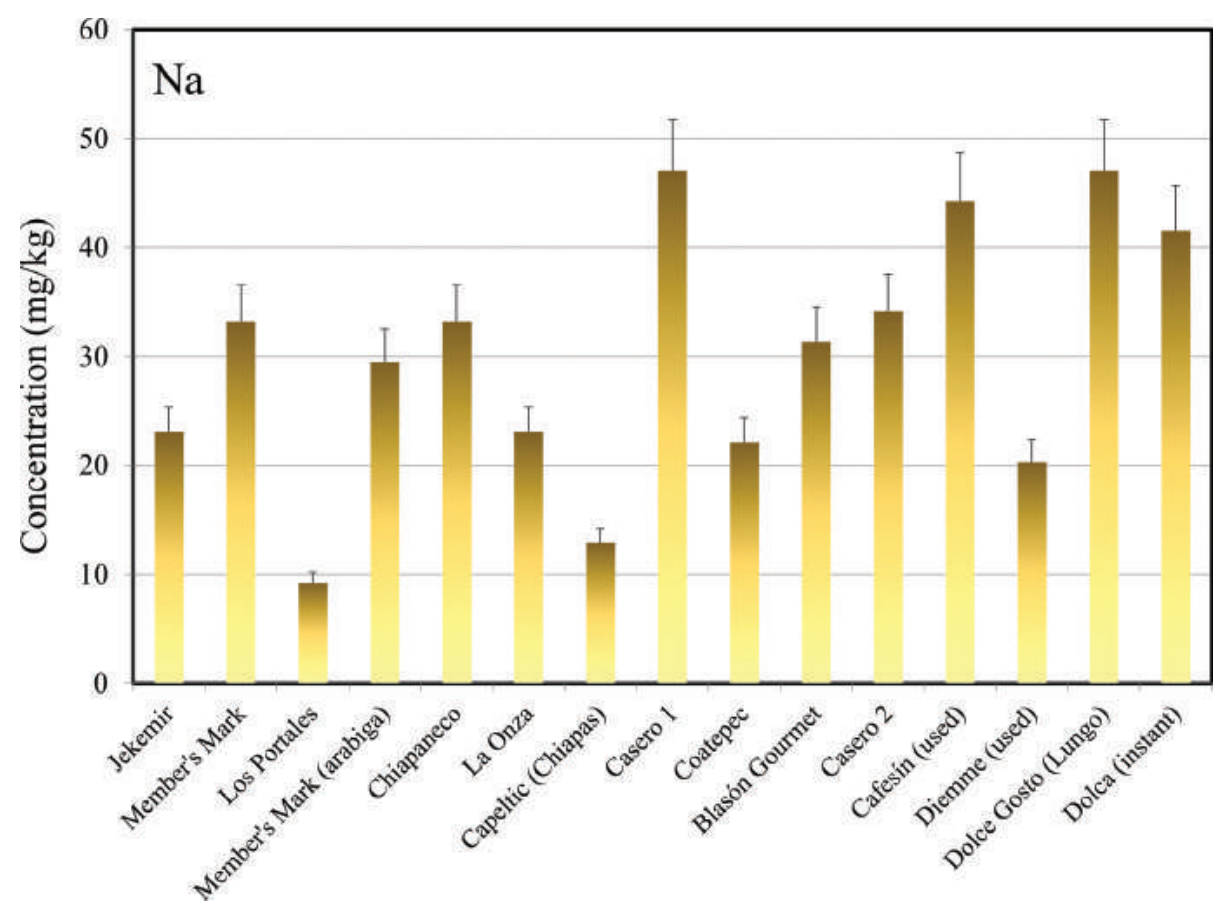

X-Ray

Fluorescence Analysis of Ground

Coffee

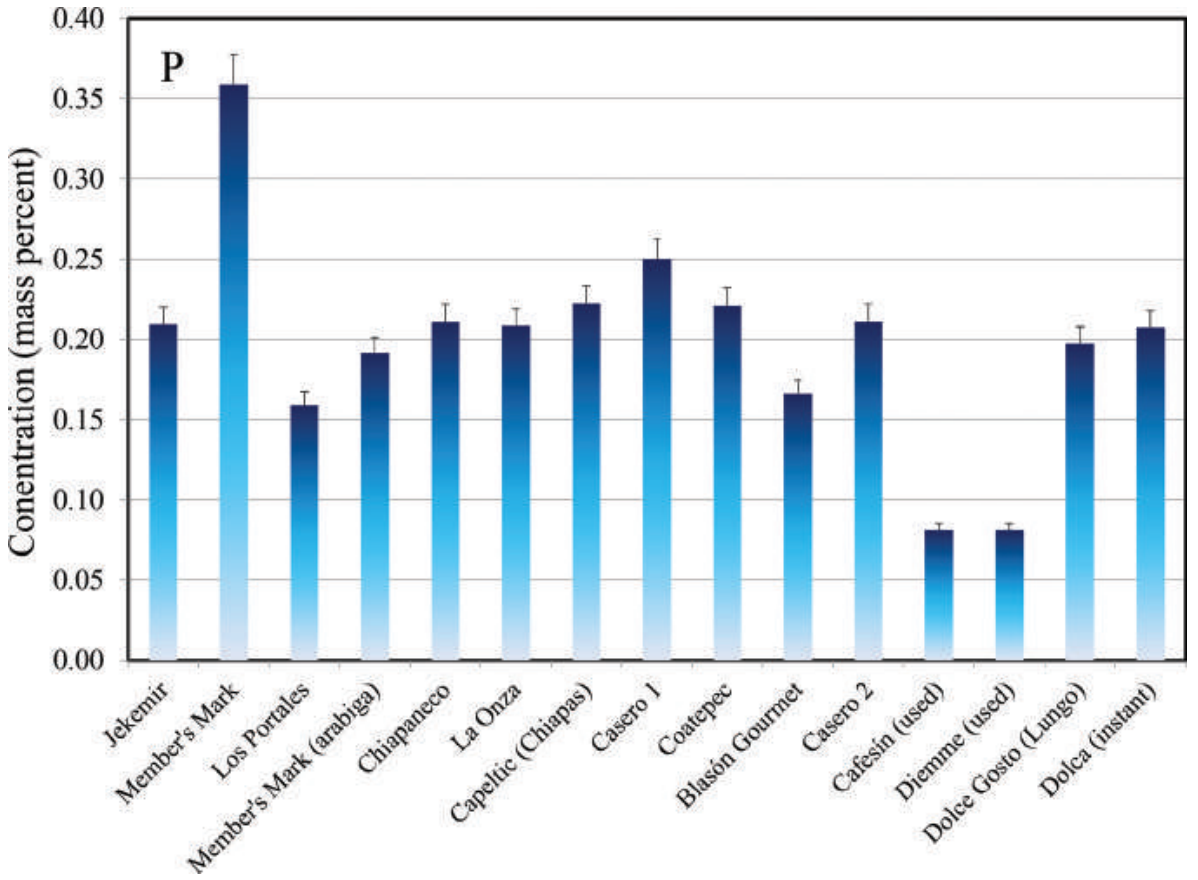


Hernández, M.C.

Romero, D.

Torres, $\mathrm{H}$.

Miranda, J.

Hernández-López,

A.E.
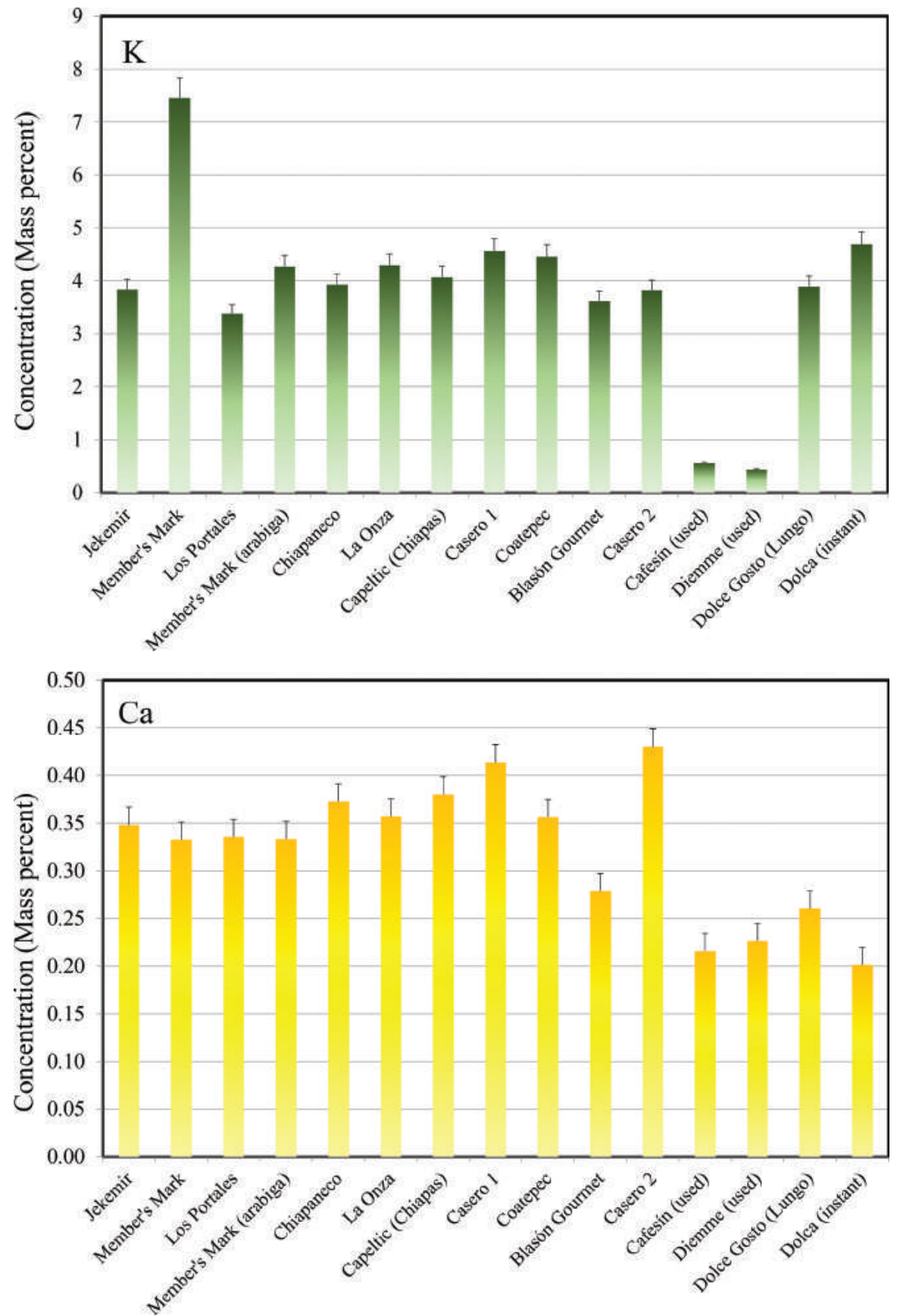

Figure 1: Concentrations of major nutrients $\mathrm{Na}, \mathrm{P}, \mathrm{K}$, and $\mathrm{Ca}$ determined in coffee samples. 


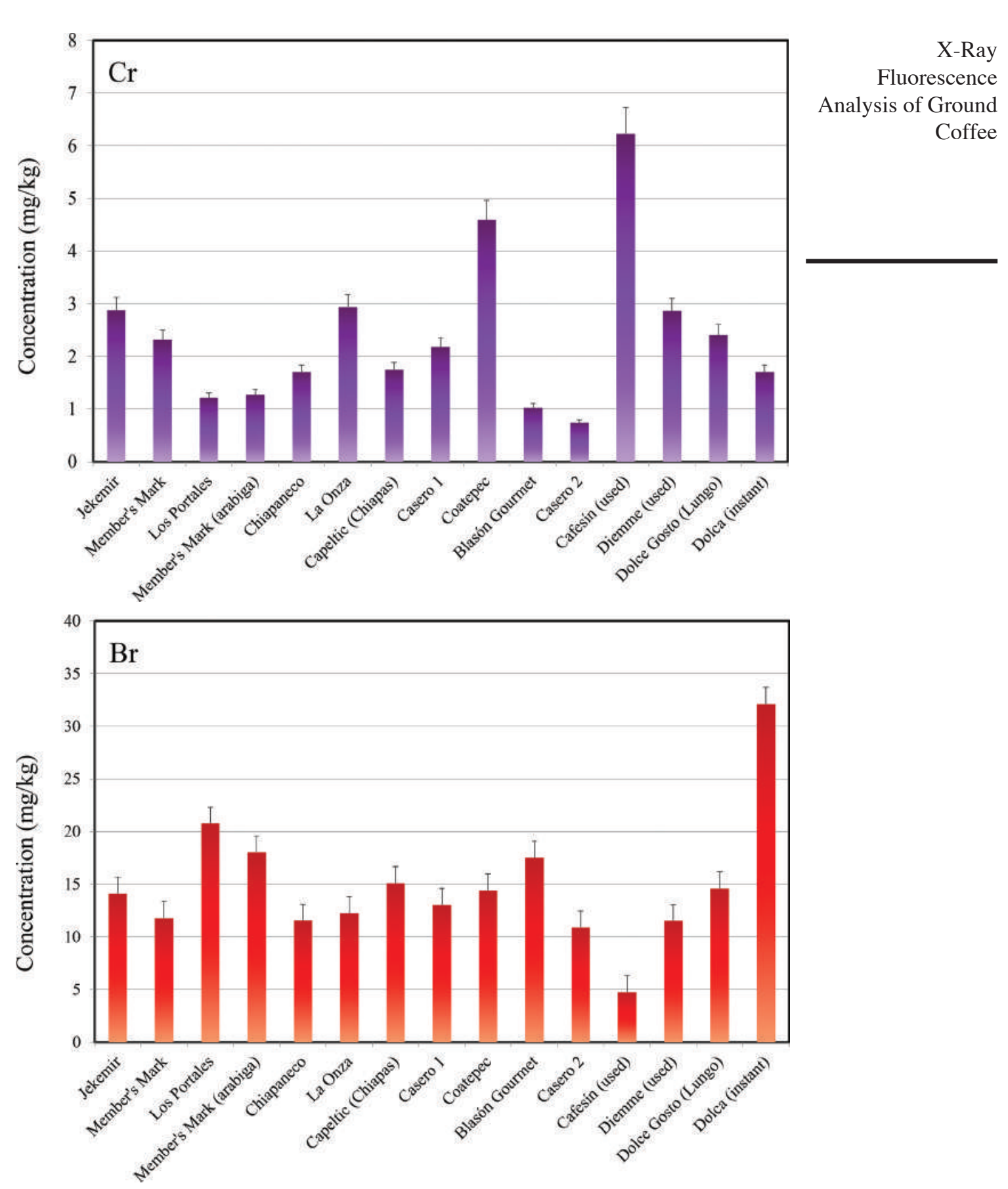

Figure 2: Concentrations of elements $\mathrm{Cr}$ and $\mathrm{Br}$ determined in coffee samples. 
Hernández, M.C. Romero, D.

Torres, $\mathrm{H}$.

Miranda, J. Hernández-López, A.E.
Table 2: Elemental concentrations determined in coffee samples: mean, minimum, and maximum for ground, coffee; used (Cafesín and Diemme), and instant coffee Dolca.

\begin{tabular}{cccccccc}
\hline Element & Units & $\begin{array}{c}\text { Mean } \\
\text { ground } \\
\text { coffee }\end{array}$ & $\begin{array}{c}\text { Minimum } \\
\text { ground } \\
\text { coffee }\end{array}$ & $\begin{array}{c}\text { Maximum } \\
\text { ground } \\
\text { coffee }\end{array}$ & $\begin{array}{c}\text { Used } \\
\text { Cafesín }\end{array}$ & $\begin{array}{c}\text { Used } \\
\text { Diemme }\end{array}$ & Dolca \\
\hline $\mathrm{Na}$ & $\mathrm{mg} \mathrm{kg}^{-1}$ & 29 & 9.2 & 47 & 44 & 20 & 42 \\
$\mathrm{Mg}$ & $\%$ & 0.20 & 0 & 0.38 & 0 & 0.11 & 0.24 \\
$\mathrm{P}$ & $\%$ & 0.22 & 0.17 & 0.36 & 0.81 & 0.81 & 0.21 \\
$\mathrm{~S}$ & $\%$ & 0.18 & 0.15 & 0.21 & 0.067 & 0.079 & 0.096 \\
$\mathrm{~K}$ & $\%$ & 4.3 & 3.4 & 7.5 & 0.55 & 0.46 & 4.7 \\
$\mathrm{Ca}$ & $\%$ & 0.35 & 0.26 & 0.43 & 0.22 & 0.23 & 0.20 \\
$\mathrm{Cr}$ & $\mathrm{mg} \mathrm{kg}^{-1}$ & 2.1 & 0.74 & 4.6 & 6.2 & 2.9 & 1.7 \\
$\mathrm{Mn}$ & $\mathrm{mg} \mathrm{kg}^{-1}$ & 47 & 18 & 82 & 13 & 26 & 14 \\
$\mathrm{Fe}$ & $\mathrm{mg} \mathrm{kg}^{-1}$ & 143 & 85 & 560 & 75 & 69 & 72 \\
$\mathrm{Cu}$ & $\mathrm{mg} \mathrm{kg}^{-1}$ & 5.8 & 2.1 & 7.6 & 6.7 & 9.9 & 1.2 \\
$\mathrm{Zn}$ & $\mathrm{mg} \mathrm{kg}^{-1}$ & 9.7 & 2.1 & 20 & 11 & 20 & 5.2 \\
$\mathrm{Br}$ & $\mathrm{mg} \mathrm{kg}^{-1}$ & 15 & 11 & 21 & 4.7 & 12 & 32 \\
$\mathrm{Rb}$ & $\mathrm{mg} \mathrm{kg}^{-1}$ & 18 & 10 & 25 & 2.5 & 9.9 & 18 \\
\hline $\mathrm{Sr}$ & $\mathrm{mg} \mathrm{kg}^{-1}$ & 35 & 17 & 49 & 8.3 & 18 & 9.2 \\
\hline
\end{tabular}

A further test in the analytical results can be carried out through a comparison with other published works where results of elemental analyses of ground coffee samples were presented. Table 3 displays such data for selected elements, compared to the average of ground coffee from this work. It is possible to see that concentrations in the latter values are of the same order as those of the previous papers, although higher for $\mathrm{K}, \mathrm{Ca}$, and $\mathrm{Fe}$. More research must be followed to find out the explanation of the higher averages.

Table 3: Comparison of elemental concentrations in ground coffee published in several studies.

\begin{tabular}{|c|c|c|c|c|c|c|c|}
\hline Source & $\begin{array}{l}\mathbf{P} \\
\%\end{array}$ & $\begin{array}{l}\mathbf{K} \\
\%\end{array}$ & $\begin{array}{c}\mathrm{Ca} \\
\%\end{array}$ & $\begin{array}{l}\mathrm{Mn} \\
\mathbf{m g} \\
\mathbf{k g}^{-1}\end{array}$ & $\begin{array}{c}\mathrm{Fe} \\
\mathbf{m g} \\
\mathbf{k g}^{-1}\end{array}$ & $\begin{array}{c}\mathbf{C u} \\
\mathbf{m g} \\
\mathbf{k g}^{-1}\end{array}$ & $\begin{array}{c}\mathrm{Zn} \\
\mathbf{m g} \\
\mathrm{kg}^{-1}\end{array}$ \\
\hline Martín et al. [7] & 0.12 & 1.27 & 0.088 & 28 & 40 & 11.9 & 5.1 \\
\hline Antoine et al. [5] & 0.14 & 1.88 & 0.13 & 23 & 39 & 12.6 & 6.3 \\
\hline
\end{tabular}




\begin{tabular}{|c|c|c|c|c|c|c|c|c|}
\hline Ranic et al. [13] & - & 1.81 & 0.11 & 33 & 39 & 18 & 6.0 & X-Ray \\
\hline $\begin{array}{l}\text { Grembecka et } \\
\text { al. [3] }\end{array}$ & 0.23 & 1.37 & 0.084 & 22 & 42 & 16.1 & 5.3 & $\begin{array}{r}\text { Analysis of Ground } \\
\text { Coffee }\end{array}$ \\
\hline $\begin{array}{l}\text { Debastiani et } \\
\text { al. [6] }\end{array}$ & 0.27 & 2.13 & 0.14 & 33 & 65 & 19.4 & 8.4 & \\
\hline Anderson [14] & 0.20 & 1.90 & 0.12 & 25 & 13 & 14.0 & 8.0 & \\
\hline This work & 0.22 & 4.30 & 0.35 & 47 & 143 & 5.8 & 9.7 & \\
\hline
\end{tabular}

As discussed in all the works cited in Table 3, the concentrations measured for every element are not expected to reach toxic levels. Regrettably, no official standards exist for elemental concentrations in ground coffee, not even in the Codex Alimentarius, the official standard for many foods developed by the Food and Agriculture Organization. Thus, it is not possible to state if the measured concentrations fulfill any official limit in ground coffee.

\section{CONCLUSIONS}

From the results presented above, it is possible to assure that the analyses with XRF are accurate. Moreover, there are significant differences in the concentrations of several elements (like P, K, Ca) among roasted ground coffee, used ground coffee, and instant coffee specimens, probably because water drags these elements during the brewing. Instant coffee has very high $\mathrm{Br}$ concentration and used coffee may present $\mathrm{Cr}$ contamination during brewing. Elemental contents are similar to those determined in previous studies of roasted ground coffee, although the average looks higher for a few cases. It is not possible to see a definite disagreement in elemental concentrations to identify origin of the samples.

For future work, an extensive collection of samples must be carried out, including more instant coffee samples. The origin of coffee samples must be clearly established, possibly with the application of multivariate statistical analysis (like Principal Component Analysis) to a wider sample set. Finally, samples obtained directly from producers might be collected.

\section{ACKNOWLEDGEMENTS}

The authors acknowledge the technical assistance of J.C. Pineda. Work supported in part by DGAPA-UNAM (PAPIME PE104814 and PAPIIT IN102615). 


\section{Hernández, M.C. REFERENCES}

Romero, D.

Torres, $\mathrm{H}$.

Miranda, J. Hernández-López, A.E.
[1] FIRA (2015). Panorama Agroalimentario: Café 2015. Mexico City: Fideicomisos Instituidos en Relación con la Agricultura (in Spanish).

[2] Tavani A., La Vecchia C. (2004) Coffee, decaffeinated coffee, tea and cancer of the colon and rectum: a review of epidemiological studies, 1990-2003. CCC, Cancer Causes Control 15(4), 743-757.

[3] Grembecka M., Malinowska E., Szefer P. (2007) Differentiation of market coffee and its infusions in view of their mineral composition, Science of the Total Environment 383(1), 59-69.

[4] Valentin, J.L., Watling, R.J. (2013) Provenance establishment of coffee using solution ICP-MS and ICP-AES. Food chemistry, 141(1), 98-104.

[5] Antoine, J.M., Fung, L. A. H., Grant, C. N. (2016) Geographic determination of the growing origins of Jamaican and international coffee using instrumental neutron activation analysis and other methods. Journal of Radioanalytical and Nuclear Chemistry, 309(2), 525-534.

[6] Debastiani, R., Dos Santos, C.E.I., Yoneama, M.L., Amaral, L., Dias, J.F. (2014) Ion beam analysis of ground coffee and roasted coffee beans. Nuclear Instruments and Methods in Physics Research Section B: Beam Interactions with Materials and Atoms, 318(2), 202-206.

[7] Martín, M.J., Pablos, F., González, A.G. (1999) Characterization of arabica and robusta roasted coffee varieties and mixture resolution according to their metal content. Food chemistry, 66(3), 365-370.

[8] Romero-Dávila, E., Miranda, J. (2004) Trace element determination in tomato puree using PIXE and Rutherford Backscattering. Journal of Radioanaytical and. Nuclear Chemistry 262(1), 355-362.

[9] Romero-Dávila, E. Miranda, J., Pineda, J. C. (2015) X-ray fluorescence analysis of Mexican varieties of dried chili peppers II: Commercial and home-grown specimens. AIP Conference Proceedings 1671, paper\#020006.

[10] Romero-Dávila, E. Miranda, J., de Lucio, O.G., Pineda, J.C. PIXE and XRF analysis of commercial breakfast cereals. 24th Conference on Application of Accelerators in Research and Industry, Fort Worth, TX, USA, October 30 to November 4, 2016.

[11] Espinosa, A.A., Reyes-Herrera, J., Miranda, J., Mercado, F., Veytia, M.A., Cuautle, M., Cruz, J.I. (2012) Development of an X-Ray Fluorescence Spectrometer for Environmental Science Applications. Instrumentation Science and Technology 40(3), 603-617.

[12] IAEA (1995). Manual for QXAS. Vienna: International Atomic Energy Agency.

[13] Ranić, M., Konić-Ristić, A., Takić, M., Glibetić, M., Pavlović, Z., Pavlović, M., Dimitrijević-Branković, S. (2015) Nutrient profile of black coffee consumed in Serbia: Filling a gap in the food composition database. Journal of Food Composition and Analysis 40(1), 61-69.

[14] Anderson, K. A., Smith, B. W. (2002) Chemical profiling to differentiate geographic growing origins of coffee. Journal of Agricultural and Food Chemistry 50(7), 2068-2075. 